\title{
MULTICULTURAL TEAMWORK AS A SOURCE OF EXPERIENTIAL LEARNING AND INTERCULTURAL DEVELOPMENT
}

\author{
Ma Del Carmen Méndez García* \\ $\mathrm{M}^{\mathrm{a}}$ Luisa Pérez Cañado* \\ University of Jaén
}

\begin{abstract}
This paper delves into multicultural teamwork as a source of experiential learning. It starts with a theoretical consideration of work in global teams, with a particular stress on the possibilities they offer for experiential learning on a cooperative and collaborative basis.

From a practical sphere, the paper presents part of the results yielded by a study on multicultural teamwork dynamics in which the opportunities these types of groups provide for learning on the spot are explored in the light of the team members' development of key components of intercultural competence.

The paper concludes with a reflection on the relevance of experiential learning for multicultural team workers' life-long learning.
\end{abstract}

Keywords: Multicultural teamwork, experiential learning, cooperative learning, intercultural (communicative) competence, (intercultural) knowledge, (intercultural) attitudes, (intercultural) skills/abilities.

\footnotetext{
Correspondence should be sent to: Dr. Ma del Carmen Méndez García. Departamento de Filología Inglesa. Universidad de Jaén. E-mail: cmendez@ujaen.es

1. This work was produced within the parameters of the Project ICOPROMO - Intercultural Competence for Professional Mobility, Programme LEONARDO DA VINCI, conceptualised, designed and coordinated by Manuela Guilherme, Centro de Estudos Sociais, Universidade de Coimbra, with the following participants: Clara Keating, Centro de Estudos Sociais, Universidade de Coimbra, Evelyne Glaser \& Alexandra Kaar, Universität Linz, María del Carmen Méndez García \& María Luisa Pérez
} 


\title{
EL TRABAJO EN EQUIPOS MULTICULTURALES COMO GERMEN DEL APRENDIZAJE EXPERIMENTAL Y DEL DESARROLLO INTERCULTURAL
}

\begin{abstract}
RESUMEN. En este artículo se contemplan las posibilidades que ofrece trabajar en equipos multiculturales para favorecer el aprendizaje experimental. El punto de inicio es la consideración teórica sobre aspectos relevantes del trabajo en equipos globales, donde se ponen de manifiesto las oportunidades que el mismo ofrece para un aprendizaje experimental basado en la cooperación y en la colaboración de sus miembros.

Desde una perspectiva más práctica, se presentan parte de los resultados obtenidos al respecto en un estudio realizado acerca de la dinámica de trabajo en equipos multiculturales en el que se exploran las oportunidades que estos equipos ofrecen para un aprendizaje in-situ a la luz del desarrollo de aspectos claves de la competencia intercultural de sus miembros.

En la conclusión se reflexiona sobre la relevancia que el aprendizaje experimental cobra en el aprendizaje permanente de los miembros de equipos multiculturales.
\end{abstract}

Palabras clave: Trabajo en equipos multiculturales, aprendizaje experimental, aprendizaje cooperativo, competencia (comunicativa) intercultural, conocimiento (intercultural), actitudes (interculturales), destrezas / habilidades (interculturales).

Received 16 March 2010

Revised version accepted 17 January 2011

\section{INTRODUCTION}

The last decades have brought about unparalleled changes at political, socioeconomic, cultural and technological level that have paved the way to the emergence of a "new world order" (Glaser et al. 2007) marked by an international flow of trade, people and ideas. Whether this new environment of internationalisation is seen as an opportunity or as a threat (Glaser et al. 2007) depends on both the general perspective the nation state has towards otherness and the individual circumstances and viewpoints themselves. Every community and every individual are undergoing these changes at their own pace and implementing their own tools. There are, nonetheless, general trends such as

Cañado, Universidad de Jaén, Terry Mughan \& Katalin Illes, Anglia Ruskin University, Annelli Kansanen, International Management Education, Guenther Zoels, Voes-Alpinen Industrieanlagenbau, and João Paulo Barbosa de Melo, Centro de Estudos e Formação Autárquica.

2. We would like to thank all the informants for their time, patience, and the valuable data with which they provided us. We would likewise like to thank the institutions they work or have worked for: Valeo (Jaén), Cruz Roja Jaén (Red Interlabora), Sun Microsystem (Madrid), Granada Acoge, European Commission (Brussels), European Space Agency (Frankfurt), CEAR (Madrid), ONU (Mexico), Unicef (Madrid), Linares Acoge, ACNUR (Madrid) and Braun Medical (Barcelona). 
the emphasis laid on language education, the creation of bilingual and plurilingual programmes in originally monolingual societies, or the consolidation of European exchange programmes (e.g. Erasmus). The results of each of these are slowly beginning to be evinced although, in general, it could be said that the young generation of Europeans is more prepared to deal with internationalisation than their predecessors.

\section{WORKING IN GLOBAL TEAMS: AN OPPORTUNITY FOR LEARNING FROM EXPERIENCE}

The presence of money, space, staff, time and the necessary tools constitute the common grounds in the creation of workgroups. However, teams may differ in a wide array of aspects, such as the number of members, the face-to-face or virtual composition of the team, its temporary or permanent existence, or its cultural diversity, to mention but a few. If the emphasis is laid on cultural diversity, a distinction can be made between token, bicultural and multicultural groups. In token groups (Earley and Gibson 2002), all the members but one share the same culture; in bicultural groups (Bachmann 2006), there is a balance between team players from two distinct cultural backgrounds; transnational, multicultural or global teams, on the other hand, contain participants from three or more communities.

All teams have commonalities towards the final goal of achieving success, the main difference among them being the greater number of variables and complexities in teams working across cultures. Cultural diversity may have both positive and negative effects on the group. On the positive side, it is important to note the presence of wider cognitive and behavioural patterns, which affect the process of task execution; the negative side seems to materialize in the interpersonal or affective domain, which becomes evident at the level of social group interaction (Bachmann 2006).

Successful transnational team membership tends to be associated with the display of very specific attributes or competences. In this respect, and from the point of view of personal or individual development, Chang and Tharenou (2004: 65-70) identify five main competences that need to be developed by a global teamwork leader or manager: cultural empathy, learning on the job, communicative competence, generic managerial skills and personal style; all of them with, possibly, the exception of the fourth element, could also be applied to all multicultural team members. The development of individual competences such as appropriate linguistic and communicative skills, cultural empathy, conflict resolution skills or learning on the job seem to be essential for transnational teamwork. In fact, given the amount of uncertainty and ambiguity inherent in 
an intercultural and plurilingual work environment, learning from experience or learning on the job emerges as a sine qua non for global teamwork.

Experiential learning is defined in the literature in a twofold way. On the one hand, Rogers (1969) equates experiential learning with significant learning and opposes it to cognitive or meaningless learning. Basically, this classroom-bound distinction reflects the dichotomy between academic learning or knowledge about something, and practical learning or knowledge about how to do something.

On the other hand, experiential learning is learning on the spot or "education that occurs as a direct participation in the events of life" (Houle 1980: 221). Kolb and Fry (1975) and Kayes et al. (2005a) consider that experiential learning depends on four factors:

To learn from its experience, a team must have members who can be involved and committed to the team and its purpose (concrete experience), who can engage in reflection and conversation about the team's experiences (reflective observation), who can engage in critical thinking about the team's work (abstract conceptualization) and who can make decisions and take actions (active experimentation). (Kayes et al. 2005a: 335)

Even though this model of experiential learning has been found to be somehow limited (Kelly 1997), Kolb and Fry's main contribution is to bring to the foreground the importance of informal learning.

Experiential learning has been conferred an unprecedented importance across disciplines, from education, management, computer/information science, psychology, medicine and nursing, to accounting or law (Kolb et al. 2000). The theory of experiential learning was initially linked to teamwork by Lewin in the 1940s (Kayes et al. 2005a) and has recently been given much consideration in connection with the workplace and the business world (Sims 1990, Beckett and Hager 2002, Nancy and Kathleen 2002). As a matter of fact, experiential learning becomes a chief aspect of global team research since "negative factors associated with teamwork can be overcome when teams become able to learn from experience" (Kayes et al. 2005a: 331).

In this sense, transnational teamwork necessarily has to be regarded as a collective, cooperative, collaborative and social learning experience. Collaboration in global teams materialises as a culture-determined and culture-bound phenomenon (Bachmann 2006, Gluesing and Gibson 2004). Since culture permeates global teamwork, cultural diversity invariably has an effect on cognition, affection and social behaviours. Cognitively, heterogeneous groups are able to bring more perspectives, suggestions and alternatives, but they also need more time to make decisions and solve problems (Bachmann 2006). Affectively, Bachmann (2006) acknowledges that team players' accounts waver from high individual satisfaction 
and commitment to stress, lack of trust and great uncertainty. In the social sphere, research indicates that the four phases of the experiential learning cycle will only be meaningful to team players if the conditions for building shared meanings are met.

One prerequisite for team members to learn from experience is the creation of a conversational space that allows for a free exchange of opinions and for group reflection and self-analysis (Kayes et al. 2005a: 332, Baraldi: 2009). Interaction allows individuals to express their interpretation of the world and how they feel towards it, hence giving way to the surfacing of a shared or common workgroup reality (Bachmann 2006). This has to be coupled with the appearance of shared mental models which facilitate coordination, cooperation, mutual trust and respect (Bachmann 2006).

Another condition is the development of mature groups where functional tasks are shared (Kayes et al. 2005a: 333-336, Kayes et al. 2005b: 357-361). This is achieved by the combination of different elements. First of all, experiential learning entails learning about the purpose. Sharing a purpose confers a group the characteristic of being a team and not a collection of individuals. In this sense, it is essential for the team to cater for both individual and collective needs. This is precisely how "group cohesion" (Bachmann 2006) can be attained, once team members feel that they are similar in salient features and experience alignment and goal agreement (Eikenberry 2007: 259). Second, role ascription and the context in which the task is to be carried out constitute additional sources of learning for team players (Kayes et al. 2005a: 345-348). Role ascription seems to vary as the group settles, with individualistic roles standing out in the initial phases and more group-oriented roles which tend to contribute towards a more balanced distribution of power at later stages. As to the context, constant adaptation to the dynamics of the team is needed as roles and tasks evolve.

Third, learning about the process implies sharing knowledge and creating new knowledge, but also being able to express one's emotions, feelings and viewpoints from different perspectives (Kayes et al. 2005a: 348-349). Experiential learning in teams correlates with the development of particular behaviours and skills such as the capacity to manage psychological stress (related to aspects such as culture shock, adjusting to a new culture and maintaining self-esteem), the ability to communicate successfully, and the ability to establish interpersonal relationships (Fowler and Blohm 2007: 347). Additional abilities comprise strong technical skills and competence, the ability and willingness to collaborate and share credit, the ability to trust others, and the ability to participate in and lead effective meetings (including the capacity to provide feedback) (Eikenberry, 2007: 264). Indeed, Kayes et al. (2005a: 349) underscore the actions taken to reach the team's purpose and, in particular, the creation of processes to provide feedback as vital aspects 
both for the process of analysing and reflecting on the course of action and as a tool to increase team members' motivation. Fourth, being a member of the group turns out to be a privileged source of experiential learning. This happens on the basis of group composition (size, diversity and compatibility, cohesion, learning style, etc.) and also, interestingly, as a result of psychological membership (Kayes et al. 2005a: 343-344). Team players will only learn if they feel, psychologically, on safe grounds; in essence, this psychological reassurance is built upon feelings such as trust and inclusion. Eikenberry (2007: 259) refers to this phenomenon as "commitment to the team and to the others" and expresses that high levels of commitment interrelate with aspects such as belief (in each other and in the team), agreements (to the set of behaviours that are acceptable to the team), trust (in team members and leadership), and support (for team decisions and each other). As Eikenberry puts it "we need people to get to know each other better. Once we have done that, we will be fine" (2007: 262). In order for experiential learning to be efficient in multicultural teamwork, Eikenberry defends the need to promote relationships among team members; this allows them to learn from each other's strengths, find ways to capitalize on those strengths and get comfortable with asking for help.

Experiential learning is not only shaped as informal learning. It also occupies a relevant position in intercultural team training. Experiential principles and assumptions seem to constitute the backbone of team training: "if there is any area or training and development in which experimental approaches are used, it is in team building" (Eikenberry 2007: 257). More specifically, Burke et al. (2005) defend experiential training for multicultural team leaders.

Hence, experiential learning and training seem to be inextricably associated with the workplace and the business world. The all-important role it plays mirrors key aspects of multicultural teamwork dynamics such as communication, leadership and teambuilding. Experiential learning impinges on team members' individual and social learning processes. In short, global teams have the potential of constituting a rich source for experiential learning as team members are in a constant dialectic process of sense-making by means of conversation and interaction with other team players.

\section{THE STUDY AND SAMPLE OF SUBJECTS}

The study reported on here is part of a large-scale investigation conducted within the framework of the 2003-2006 ICOPROMO Project, approved and funded by the European Commission Leonardo da Vinci programmes. ICOPROMO, Intercultural Competence for Professional Mobility, has aimed at providing students and professionals with tools to develop intercultural competence for professional 


\begin{tabular}{|c|c|c|c|c|c|}
\hline \multicolumn{6}{|c|}{ TEAM MEMBERS ACCESSED BY THE SPANISH PARTNER } \\
\hline $\mathbf{N}^{\circ}$ & NATIONALITY & GENDER & AGE & AREA (name of institution/corporation, location) & $\begin{array}{l}\text { TYPE OF } \\
\text { INTERVIEW }\end{array}$ \\
\hline 1 & Spanish & Female & 34 & Business (VALEO, Jaén, Spain) & Face-to-face \\
\hline $2^{*}$ & Spanish & Female & 35 & NGO (RED CROSS, Jaén, Spain) & Face-to-face \\
\hline $3^{*}$ & French & Male & 32 & $\begin{array}{l}\text { Business (SUN MICROSYSTEMS, Madrid, } \\
\text { Spain) }\end{array}$ & Face-to-face \\
\hline 4 & Spanish & Female & 41 & NGO (GRANADA ACOGE, Granada, Spain) & Face-to-face \\
\hline $5^{*}$ & Spanish & Male & 35 & $\begin{array}{l}\text { Intergovernmental Relations (EUROPEAN } \\
\text { COMMISSION, Brussels, Belgium) }\end{array}$ & Face-to-face \\
\hline 6 & Spanish & Male & 28 & $\begin{array}{l}\text { Business (SUN MICROSYSTEMS, Madrid, } \\
\text { Spain) }\end{array}$ & Telephone \\
\hline $7^{*}$ & Spanish & Male & 37 & NGO (CEAR, Madrid, Spain) & Face-to-face \\
\hline 8 & Spanish & Male & 31 & $\begin{array}{l}\text { Business (EUROPEAN SPACE AGENCY, } \\
\text { Frankfurt, Germany) }\end{array}$ & Telephone \\
\hline 9 & Colombian & Male & 32 & NGO (CEAR, Madrid, Spain) & Face-to-face \\
\hline 10 & Spanish & Male & 34 & $\begin{array}{l}\text { Intergovernmental Relations (EUROPEAN } \\
\text { COMMISSION, Brussels, Belgium) }\end{array}$ & Telephone \\
\hline $11^{*}$ & Spanish & Female & 36 & $\begin{array}{l}\text { Intergovernmental Relations } \\
\text { (UNITED NATIONS, Madrid, Spain) }\end{array}$ & Face-to-face \\
\hline 12 & Spanish & Female & 31 & $\begin{array}{l}\text { NGO (UNICEF, Madrid, Spain; Mexico city, } \\
\text { Mexico) }\end{array}$ & Face-to-face \\
\hline 13 & Spanish & Female & 49 & NGO (LINARES ACOGE, Jaén, Spain) & Face-to-face \\
\hline 14 & Spanish & Female & 29 & $\begin{array}{l}\text { Intergovernmental Relations (ACNUR, Ma- } \\
\text { drid, Spain) }\end{array}$ & Face-to-face \\
\hline $15^{*}$ & Dutch & Male & 24 & $\begin{array}{l}\text { Business (BRAUN MEDICAL, Barcelona, } \\
\text { Spain) }\end{array}$ & Telephone \\
\hline 16 & Icelandic & Male & 29 & $\begin{array}{l}\text { Business (BRAUN MEDICAL, Barcelona, } \\
\text { Spain) }\end{array}$ & Telephone \\
\hline & & & ${ }^{*} \mathrm{~h}$ & been interviewed twice & \\
\hline
\end{tabular}

Table 1: The global team members interviewed by the Spanish partner 
mobility. At the time this study was conducted the ICOPROMO team was made up of four academic partners ${ }^{1}$ and three professional partners ${ }^{2}$.

The study presented here corresponds to the line of action taken in 2004, when the academic partners conducted fieldwork among multicultural team members in Austria, Germany, Portugal and Spain to investigate the dynamics of transnational teams. The main goal was to have a first-hand approach to different issues related to the development of intercultural competence in multicultural team players. In order to obtain valid and comparable data the ICOPROMO team agreed that a) the study would take place among members of global teams with at least one year of experience in multicultural teamwork either in intergovernmental organisations, NGOs, or the business sector; b) the multicultural team members either had to be born in any of these four countries and work in the country itself or abroad, or had to be born elsewhere and work in any of the four countries.

This paper presents the findings obtained in Spain given that each partner was in charge of administering and analysing the data yielded in its own country. The outcome of a comparative study was agreed to be published in a particular volume (Glaser et al. 2007). The total number of participants accessed by the Spanish partner are sixteen, seven women and nine men in their 20s, 30s (mostly) and 40 s (the minority) from five different nationalities. In order to give validity and reliability to the study, the maximum number of interviewees was limited to two per institution. The table above or Table 1 contains contextual information about the participants - such as their nationality, gender, age and the institution they were working for at the time of the study - as well as about the interview process (number of times each participant was interviewed and type of interview).

Considering the impossibility of collecting data through structured and unstructured observation within the teams for practical reasons, it was decided that the best research tool for the ICOPROMO purposes, gaining an insight into the development of intercultural competence in actual multicultural team dynamics, would be interviews. Indeed, it was questionable whether we would have been granted permission for conducting observation; additionally, as table 1 indicates, some of the interviews had to be done by means of telephone conversations given the distance between the academic partners' institutions and the interviewees' place of work.

The qualitative data obtained was considered to be highly relevant for the purposes of the project and this is why the team decided to complement it later with further quantitative research conducted in 2007 (see Glaser et al. 2007).

\footnotetext{
1 Portugal (Universidade de Coimbra, coordinator), Germany (Universität Göttingen), Austria (Universität Linz), and Spain (Universidad de Jaén).

2 Finland (International Management Education), Austria (Voes-Alpinen Industrieanlagenbau, now Siemens), and Portugal (Centro de Estudos e Formação Autárquica).
} 
The choice of interviews as a research tool rests on their versatility and on the possible new light they may shed on issues that had not previously been contemplated by the interviewer. The ICOPROMO team was aware that interviews have limitations, such as the fact that individuals may try to be politically correct and avoid speaking about a particular issue and even the fact that they may strive to conceal their real feelings and opinions (and this is a factor we sometimes encountered); a further disadvantage is the amount of time needed to contact interviewees, set a date for the interviews, gather and transcribe the data and analyse the heterogeneous responses. Needless to say, the team employed the content analysis technique to classify and examine the data. For the sake of validity and reliability, a one-to-one model of structured interviews was selected, even though open questions were never excluded and were indeed formulated during the process.

In each of these four countries, two rounds of interviews took place from February to July 2004. The first round of interviews conducted among sixteen interviewees, ranged from 25 to 40 minutes and explored general aspects of teamwork dynamics and intercultural competence such as the characterisation of the multicultural teams the interviewee had been involved in, the ways of communicating and coordinating work, issues of efficiency, reasons for conflict (if any) and possible actions taken to solve them, and issues of influence in global groups (Appendix 1 contains the guiding questions formulated to the participants).

The first round of interviews yielded an extremely valuable and rich amount of data in different areas of interest - such as the relationship between the vehicular team language and power (Méndez García and Pérez Cañado 2005), verbal and non-verbal aspects in intercultural communication (Pérez Cañado and Méndez García 2007), and further key issues of group dynamics like intercultural interaction, intercultural responsibility, emotional management or diversity management (Glaser et al. 2007, Guilherme et al. 2010) to name but a few. Accordingly, the ICOPROMO team decided to proceed to a second round of interviews. In the four countries, the second round of interviews shorter than the first on average, was carried out among six of the interviewees approached in the first round marked with an asterisk in Table 1, two belonging to each field (intergovernmental organisations, NGOs and the business sector). The decision of selecting six interviewees per country rested on both methodological and practical criteria. The ICOPROMO team assumed that it would be neither feasible nor desirable to interview all the individuals that had participated in the first round of interviews as the aim of the second round was not to obtain completely unexplored data but rather to confirm or refuse what we considered to be the most outstanding findings of the first round. As to the selection of informants the Spanish partner was convinced that the study would be more valid and reliable if 
interviewees were diverse and heterogeneous. Therefore, in the selection process the Spanish partner contemplated, among others, the following variables:

- Gender: a balanced number of males and females.

- Nationality: participants from different nationalities.

- Region: individuals working in different parts of Spain and abroad.

- Experience: interviewees with a restricted and with an extensive experience in multicultural teamwork.

It was agreed that six questions should guide the interview and should appear in the following order (the guiding questions used by the Spanish partner appear in Appendix 2): a) a question particular to the interviewee and derived from his/her first interview; b) two national questions; c) three transnational questions. The second of the two national questions formulated by the Spanish partner aimed at gaining insight into one of the issues that was widely debated during the first round of interviews: the importance of multicultural teamwork for personal and professional growth. This way we managed to gather many of the fundamental cognitive, attitudinal and skill factors of teamwork dynamics as a source of experiential learning which individuals had commented on at-length during the first round.

The leading question centred around the possibilities multicultural teamwork offers when it comes to acquiring knowledge, changing attitudes and developing specific skills or abilities. This paper reports on the results obtained on the basis of the formulation of this final question during the second round of interviews. The goals of this part of the study were the following:

- To find out the possibilities global group work offers for experiential learning, both understood as an individual and, mainly, a cooperative process.

- To ascertain the potential of multicultural teamwork for intercultural relations and intercultural learning.

- To discover specific instances of intercultural communicative competence (as a make-up of knowledge, attitudes and skills) developed by global team members which have resulted from experiential learning in their particular work context.

The two rounds of structured interviews were configured to reveal significant aspects of experiential learning in groups, such as the role of conversation, interaction and mediation to reach intercultural understanding (Kayes et al. 2005a: 332, Bachmann 2006, Baraldi 2009); the different domains contributing to group cohesion (Bachmann 2006); the establishment of interpersonal relations and rapport (Eikenberry 2007); the acquisition of knowledge and the development of attitudes, skills and behaviours (Kayes et al. 2005a, Eikenberry 2007, Fowler and Blohm 2007); the commitment to the group and to the others (Eikenberry 2007); or the mechanisms for exchanging ideas and providing feedback (Kayes et al. 2005a). 
This paper primarily focuses on multicultural teams as a source of experiential learning that favours the development of the different components of intercultural competence. The findings will be presented according to the paradigm of intercultural competence proposed Byram et al. (2002), which has many commonalities with some of the categories underlined by Kayes et al. (2005a), Eikenberry (2007) and Fowler and Blohm (2007).

\section{FINDINGS: LEARNING FROM EXPERIENCE IN MULTICULTURAL TEAMS AND THE DEVELOPMENT OF INTERCULTURAL COMMUNICATIVE COMPETENCE}

Multicultural teamwork constitutes a valuable opportunity for transnational team members' experiential learning, personal growth and intercultural development.

Informants were willing to expand on the personal benefits they constantly derive from such a versatile work environment in the course of the two rounds of interviews, although they did so in a much more informal and unstructured way in the first round (mainly to illustrate different issues concerning global team dynamics). The data yielded comprehends diverse components of intercultural communicative competence development in the following three main areas such as knowledge, attitudes and skills (following Byram et al. 2002).

\subsection{INTERCULTURAL KNOWLEDGE}

Multicultural teams are unanimously seen as an excellent source of cultural knowledge or information. The member from a particular culture appears as the carrier of cultural elements like customs, history or gastronomy ${ }^{3}$.

La información (...) el aprendizaje de sus costumbres (...) Mira, he conocido lugares, bistoria, gastronomia. (2.2)

Global teams likewise promote participants' learning about new viewpoints and lifestyles. Shared perceptions (Bachmann 2006) are determined by a reflection on how group members represent each other, their world view and norms.

Lo que sí es los países, pero es una cosa más social ¿no? No tiene nada que ver con el trabajo, pero si que también te expliquen cosas de su país, de cómo funcionan las cosas y cada uno explica su guía. (2.5)

One of the most outstanding elements of a culture is its language, and interviewees make clear that the development of their plurilingual competence,

\footnotetext{
3 The numbers in brackets indicate, in this order, the round of interview (first or second) and the number of interviewee (1-16 in the first round and 1-6 in the second).
} 
now a topical issue in Europe (Common European Framework of Reference for Languages, 2001), not only rests on other team members as a source of information, but also seems to pave the way to the creation of a relaxed atmosphere and the building of trust. Therefore, Kayes et al.'s assertion that experiential learning in teams is greatly dependent on the creation of a conversational space (2005a) is here given a further dimension. If the command of the vehicular team language is a prerequisite for communication, the establishment of a conversational space undeniably benefits from a basic command of expressions in the languages of other team members and an interest in their culture.

Otra cosa era que, para entablar las conversaciones, se rebajen las barreras entre las personas de las diferentes nacionalidades era el intentar aprender palabras de los otros idiomas, aunque no fuera del idioma que está usando. A los alemanes les gustaba mucho que les dijese cuatro tonterías en alemán y a los italianos también les gustaba que les dijeras tonterías en italiano o que les preguntases cosas de su pais. $(1.6)^{4}$

Another area which stands out is gaining knowledge specific to the position beld or the function fulfilled. Achieving this strong technical competence (Eikenberry 2007 ) is coupled with learning about the process and about the task (Kayes et al. 2005a: 346-348):

Conocimientos muchísimos -obviamente las materias que se trabajan en esta organización, que no eran la que trabajaba antes. (2.2)

Similarly, the study corroborates that, cognitively, the cultural diversity implicit in global teams helps their members give consideration to new perspectives. Hence, they are likely to contribute with a wider variety of alternatives (Bachmann 2006). A sample, for instance, is problem-solving:

Well, as to 'knowledge', of course, you are able to acquire different problem-solving skills that are based on different cultural approaches. (2.6)

To sum up, on the cognitive domain, experiential learning in the global workplace has the potential to foster citizens' global education, widening their horizons and assisting them in their acceptance of diverging viewpoints as long as the foundations are laid on a mediated, collaborative and co-operative exchange. This, unquestionably, plays a major part in the alignment of team members' frames

\footnotetext{
4 Even though this paper focuses on the results obtained in the second round of interviews, as it has been previously stated, the second round echoes and expands on important aspects which cropped up in the first round. Therefore, some illustrative quotations have been extracted from the first round of interviews for the sake of clarity, consistency and depth of analysis.
} 
of reference or interpretation (Bachmann 2006) and facilitates the process of sharing knowledge and creating new knowledge (Kayes et al. 2005a). Both turn out to be crucial facets of experiential learning in teams.

Es enriquecedor desde el punto de vista cultural, desde el punto de vista de otras formas de pensamiento, otras formas de aproximación a los problemas y a solucionarlos. (23)

\subsection{INTERCULTURAL ATTITUDES}

In a comparative study of European project groups Chevrier (2003: 7) acknowledges that attitudes such as openness, patience and self-control make for effective multicultural teamwork. In our study, curiosity is seen as an excellent starting point in multicultural teamwork. Its potential as a driving factor cannot be underestimated (Berlyne 1950):

Por curiosidad..., por riqueza misma (...). Hay que tocar, probar, ver cómo funcionan las cosas. (1.3)

The Spanish sample brings up attitudes such as tolerance, although some of the interviewees acknowledge possessing it before participating in the transnational group. Tolerance encapsulates the meaning of accepting otherness and also, according to the informants, personal adaptation, a more demanding and selfconscious phenomenon. In the professional realm, tolerance is also associated with pushing personal preferences to the background and taking on a more collectivistic stance (Bachmann, 2006, Kayes et al. 2005):

Quizás más que tolerancia, para que entiendas, es como adaptación propia (2.2) Mira, la tolerancia tienes que (...) una de las cosas importantísimas que hay es eso, intentar individualizar mucho menos las cosas y pasar a verlas en un plano colectivo, en un terreno colectivo como trabajadores de grupo, ¿sabes?. (2.2)

Empathy, the feeling of concern for others, is more complex than tolerance, going beyond the mere acceptance of others and leading to a shift in perspective. Multicultural team members value empathy as a major disposition for real understanding and, as a consequence, speak about the need of putting oneself into somebody else's shoes and embracing other ways of looking at the world:

Pues mira, muchísima empatía. (2.2)

Ponerme más en su lugar. (2.1)

Interviewees believe that their intercultural experience in the workplace aids them to adopt some of the attitudes they see in colleagues. Importantly, collaborative learning experience reduces or even eliminates prejudices. 
Desde luego hay actitudes de otros que no be cogido y que no me gustan nada y, claro, esas no las cojo, pero cojo las que supongo que me enriquecen a mi. (2 3) Te quita prejuicios. (2.3)

In spite of this, team members do not see flexibility (Bachmann 2006) as a natural phenomenon, but rather as a goal towards whose achievement the individual has to put considerable effort and about which s/he has to learn:

As to the attitudes, of course, if you have to work in a multicultural environment, you have to be able to be flexible, and this flexibility is not only sometimes a gift from God or something embedded in your genes but something that you learn. (2.6)

To summarise, the Spanish sample confirms the all-important role of specific attitudes in successful multicultural team workers: tolerance (Chevrier 2003: 145), openmindedness (Chevrier, 2003: 145), flexibility (Lagerström and Andersson 2003: 91, Marschan-Piekkari et al. 1999: 422, Bachmann 2006) and empathy (Glaser et al. 2007). Likewise, in terms of attitudes, this study agrees with Chang and Tharenou's (2004: 65-70) competences of cultural empathy and learning on the job, the former stressing the recognition of difference in perspective, and the latter embodying attitudes such as flexibility, adaptability or tolerance. Even though most of these attitudes are not explicitly acknowledged by experts on experiential learning such as Kayes et al. the data reveal that multicultural group work demands the emergence and display of the aforementioned attitudes which, in this sense, are clearly determined by and, in turn, give way to the necessary conversational space. It is through these central attitudes that the team will allow for the indispensable expression of inner needs and feelings (Kayes et al. 2005a: 349).

\subsection{INTERCULTURAL SKILLS OR ABILITIES}

DiStefano and Maznevski (2000: 52) use the term "empathy in practice" or "listening to others and responding to them", to refer to the ability to decentre, which implies suspending judgement and fighting against the human tendency to view difference as bad or inferior. Putting oneself in somebody else's shoes or second intuition is envisaged as one of the main abilities in a multicultural teamworker; it originates in shifting one's culture-bound stance, not as easy a skill as it may seem since it requires leaving aside elements from one's culture, language and even one's mind. This series of minute and constant adjustments seem to stem from the ability to truly listen and inevitably lead to thinking in a different way:

Cosas que he aprendido, pues sobre todo el aprender a ponerme a veces en el lugar del otro, puesto que a veces perciben las cosas de distinta manera. (2.2) 
Aprendes otras formas de pensar diferentes (...) otras formas de aproximación a los problemas y a solucionarlos. (2 3)

The development of intercultural competence necessitates anchoring new knowledge and competences on previous ones in a constant dialectic process of learning, unlearning and relearning (Glaser et al. 2007). As a consequence, the skill of comparing one's knowledge and viewpoints with the way other people see the world (Byram et al. 2002) is vital:

A veces aplicar cosas que me parecen buenas de la vida de mis compañeros a mi vida. (2.1)

Changing one's mind goes hand in hand with the skill of personal adaptability, of making the effort to cope with the necessary adjustments to deal with and truly understand the other (Bachmann 2006), a two-way process which does not work if there is no will on both sides; hence the need for a conversation space which allows cooperative learning (Kayes et al. 2005a).

La adaptación personal a las formas de ser del otro. (2.2)

Yo creo que eso tiene que ser absolutamente un periodo de adaptación total y mutua. (2.2)

Adopting the ability to be flexible (Bachmann, 2006) and developing problemsolving skills are interestingly related by one interviewee to the relevance of correctly using the devices of verbal and non-verbal communication. This goes along the lines of Henderson (2005: 71-72), who confers a great importance to the capacity to recognise routines and rituals, and the skill to discover and correctly interpret contextual cues or signals (Glaser et al. 2007).

The main skill that you acquire is the ability to be flexible and to approach a different problem both in terms of verbal or written communication with others and also from the substantive perspectives from a number of different angles. (2.6)

Communication and flexibility occupy a relevant position at all levels, verbal and non-verbal. There are aspects some members of the group need to alter if they want to keep up with team members from different cultural backgrounds whose ways of doing things are demonstrated to be more fruitful. In Eikenberry's (2007) terms, this is the ability and willingness to collaborate and share credit and it can only surface in a climate of trust and safety (Kayes et al. 2005a: 342) where team players are able to develop the capacity to manage psychological stress (Fowler and Blohm 2007):

Los nórdicos suelen ser más meticulosos (...) Entonces, pues hacer las cosas de una manera distinta, dejar las cosas menos a la improvisación y más a la preparación (...) 
Los españoles somos más dados a improvisar y a no prepararnos las reuniones. (23)

Developing the appropriate communicative skills or, in other words, exhibiting the ability to communicate effectively (Fowler and Blohm 2007), in a broader sense, arises from the rapport established with the interlocutor to the extent of considering his/her current state of mind in order to cautiously select the suitable register to be used. As a French interviewee states, for him, it is relatively easy to proceed to this selection in a relatively short span of time with his own fellow countrymen, but it takes much more care and time to reach conclusions when somebody comes from a different cultural background.

Lo que me ha mejorado, por ejemplo, a la hora de hablar con otra persona, dedicar al principio un poquito de tiempo para saber quién es y en qué estado está (...) dedico un tiempo a saber con quién estoy hablando y en qué estado está y, según eso, decido el registro que voy a usar con él. (2.4)

To conclude, multicultural team work favours the development of intercultural abilities which cater for a variety of situations and which lead global team members to cooperation on the basis of mutual respect and trust. An elemental factor in the creation of this climate at work is the promotion of non-taskrelated communication activities, social rituals or ceremonies linked to the ability to establish interpersonal relations (Fowler and Blohm 2007) so as to build a sense of a community (Bachmann 2006, Gluesing and Gibson 2004). In our sample fostering mutual respect and establishing personal links with the members of one's multicultural team are acknowledged to be exceptionally useful for relationship-building in this particular work context. Specific instances include organizing meetings, professional and extra-professional activities, or trips fostering participants' getting to know each other more deeply:

Convivencia con eso, con tema lúdico, en la que haya que compartir forzosamente tiempo y espacio. (1.6)

\section{CONCLUSION}

In spite of the fact that some time has elapsed from the moment when the interviews were conducted, the authors are convinced that the competences brought to the foreground by the informants - which are likewise widely acknowledged in the literature - seem to be central in the development of intercultural competence based on experiential learning in multicultural work placements. Therefore, it is believed that the temporal dimension can probably be looked at as a relatively irrelevant factor in this respect. 
The interviewees in the Spanish sample confirm, following Chang and Tharenou (2004) or Kayes et al. (2005a), that multicultural teamwork affords individuals numerous possibilities to learn on the job and this greatly adds to their life-long learning. Respondents seem to make the most of the opportunities their workplace offers them to carry out their own experiential learning. The construction of an appropriate communication space (the cornerstone of experiential learning according to Kayes et al., 2005a) will only materialise if the climate and conditions of the work context allow team members to improve and develop their intercultural competence. Consequently, multicultural teamwork presents the potential to assist the team member to develop the appropriate tools to become a real ethnographer and truly learn from experience.

The foundations of experiential learning rest on a great dose of reflection on the concrete experience and on abstract conceptualization leading to active experimentation. The study shows how intercultural learning in global work contexts greatly correlates with the four stages of the never-ending experiential learning cycle (Kayes et al. 2005a: 334) in a constant learning, unlearning and relearning process (Glaser et al. 2007) of cooperation, collaboration and mediation.

To what extend the collective (melting pot) or the individual (tossed salad) needs to prevail in a balanced global team is an issue worth being considered as Bachmann (2006) advises against the dangers of homogenization vs. the dangers of having a "collection of individuals" rather than a team. What seems to be evident is that interpersonal demands (Kayes et al. 2005a) are more persistent in transnational teams than in any other type of workgroup.

Multicultural or intercultural encounters become a highly inspiring experience, not only at the professional but also at a deep personal level:

La multiculturalidad te da mucha riqueza de perspectivas, y de visión. Aprendes mucho, te hace percibir cosas que te enriquecen mucho porque es otro punto de vista totalmente de enfrentar los problemas pero que muchas veces dices pues a lo mejor es más acertado que el que yo estoy teniendo', y puedes llegar en un momento dado a decir, entre los dos, 'vamos a poner un poco de lo mío y otro poco de lo tuyo' y sale algo todavía más rico. (1.11)

To put it in a nutshell, a present thriving force and the working force of the future, multicultural teamwork offers numerous possibilities for experiential and life-long learning both as an individual and, chiefly, as a collective phenomenon leading to the development of truly intercultural citizens.

\section{REFERENCES}

Bachmann, S. 2006. "Melting pot or tossed salad? Implications for designing effective multicultural workgroups”. Management International Review 46 (6): 721-747. 
Baraldi, C. 2009. Experiential learning as an effective method of developing intercultural communicative competence and global citizenship. Lecture presented the Seminar Learning by Doing: Intercultural Communicative Competence and Global Citizenship from a Young Age, London, United Kingdom.

Beckett, D. and P. Hager. 2002. Life, Work and Learning: Practice in Postmodernity. London: Routledge.

Berlyne, D. E. 1950. "Novelty and curiosity as determinants of exploratory behaviour". British Journal of Psychology 41: 68-80.

Burke, C. S., Hess, K. P., Priest, H. A., Rosen, M., Salas, E., Paley, M. and S. Riedel, 2005. Facilitating leadership in a global community: a training tool for multicultural team leaders. Paper presented at the Interservice/Industry Training, Simulation, and Education Conference (I/ITSEC) 2005, Orlando, FL. http://www.aptima.com/publications/2005_Burke_Hess_Priest_Rosen_Salas_ Paley_Riedel.pdf (Accessed 9 May 2007).

Byram, M., Gribkova, B. and H. Starkey. 2002. Developing the Intercultural Dimension in Language Teaching. A Practical Introduction for Teachers. Strasbourg: Council of Europe.

Chang, S. and P. Tharenou. 2004. "Competencies Needed for Managing a Multicultural Workgroup”. Asia Pacific Journal of Human Resources 42 (1): 57-74.

Chevrier, S. 2003. "Cross-cultural Management in Multinational Project Group". Journal of World Business 38 (2): 1-13.

DiStefano, J. J. and M. L. Maznevski. 2000. "Creating Value with Diverse Teams in Global Management”. Organizational Dynamics 29 (1): 45-63.

Eikenberry, K. 2007. "Experiential learning in team training". The Handbook of Experiential Learning. Ed. M. Silberman. New York: John Wiley \& Sons, Inc. 256-271.

Earley, P. C. and C.B. Gibson. 2002. Multinational Work Teams: A New Perspective. Mahwah (New Jersey): Lawrence Erlbaum Associates.

Fowler, S., and J. Blohm. 2007. Experiential learning in intercultural training. The Handbook of Experiential Learning. Ed. M. Silberman. New York: John Wiley \& Sons, Inc. 341-359.

Glaser, E., Guilherme, M., Méndez García, M.C. and T. Mughan. 2007. Intercultural Competence for Professional Mobility. Strasbourg: Council of Europe.

Gluesing, J. C. and C. B. Gibson. 2004. Designing and forming global teams. The Blackwell Handbook of Global Management: A Guide to Managing Complexity. Eds. H. W. Lane, M. L. Maznevski, M. E. Mendenhall and J. McNett. Oxford: Blackwell Publishing. 199-226. 
Guilherme, M., E. Glaser and M. C. Méndez García (eds.). 2010. The Intercultural Dynamics of Multicultural Working. Clevedon: Multilingual Matters.

Henderson, J. K. 2005. "Language diversity in international management teams". International Studies of Management and Organisation 35 (1): 66-82.

Houle, C. 1980. Continuing Learning in the Professions. San Francisco: Jossey-Bass.

Kayes, D. C., Kayes, A. and D. A. Kolb. 2005a. "Experiential learning in teams". Simulation and Gaming 36 (3): 330-354.

Kayes, D. C., Kayes, A. and D. A. Kolb. 2005b. "Developing teams using the Kolb Team Learning Experience". Simulation and Gaming 36 (3): 355-363.

Kelly, C. 1997. David Kolb, the theory of experiential learning and ESL. The Internet TESL Journal, III, 9. http://aitech.ac.jp/ iteslj/Articles/Kelly-Experiential/ (Accessed 9 May 2007).

Kolb, D. A. and R. Fry. 1975. Toward an applied theory of experiential learning. Theories of group process. Ed. C. Cooper. London: John Wiley. 33-57.

Kolb, D.A., Boyatzis, R.E. and C. Mainemelis. 2000. Experiential learning theory: previous research and new directions. Perspectives on cognitive, learning and thinking styles. Eds. R.J. Sternberg and L.E Zhang. Mahwah, NJ: Lawrence Erlbaum. 227-247.

Lagerström, K., and M. Andersson. 2003. "Creating and sharing knowledge within a transnational team: the development of a global business system". Journal of World Business 38 (2): 84-95.

Marschan-Piekkari, R., Welch, D. E. and L. S. Welch. 1999. "In the shadow: the impact of language on structure, power and communication in the multinational". International Business Review 8 (4): 421-440.

Méndez García, M.C. and M. L. Pérez Cañado. 2005. "Language and power: raising awareness of the role of language in multicultural teams". Language and Intercultural Communication 5 (1): 86-104.

Nancy, A. and A. Kathleen. 2002. "Developing multicultural counseling competencies through experiential learning". Counselor Education and Supervision 42 (1): 2-14.

Pérez Cañado, M. L. and M. C. Méndez García. 2007. "Intercultural Communication in the Global Workplace: The Case of Multicultural Teams in Spain”. Cultura, Lenguaje y Representación 4: 185-202.

Rogers, C.R. 1969. Freedom to Learn. Columbus, OH: Merrill.

Sims, R. R. 1990. An Experiential Learning Approach to Employee Training Systems. New York: Quorum Books.

The Common European Framework of Reference for Languages. 2001. Strasbourg: Council of Europe. 
ICOPROMO: Intercultural Competence for Professional Mobility

First Round of Interviews

Guiding questions ${ }^{1}$

1. ¿Podría usted caracterizar brevemente los equipos multiculturales de los que ha formado parte? ¿Qué culturas estaban representadas en el/los equipo/s? ¿Durante cuánto tiempo han estado funcionado el/los equipo/s multicultural/ es?

2. ¿Cómo se comunicaban/comunican entre sí y coordinaban/coordinan su trabajo?

3. ¿Qué equipos multiculturales fueron/son los más eficaces? ¿Por qué? En caso de haber formado parte de un solo equipo multicultural, ¿lo encontró eficaz? Justifique su respuesta.

4. Si surge algún tipo de conflicto en un equipo multicultural, ¿cuáles cree usted que son las principales causas según su experiencia?

5. Si ha contestado afirmativamente a la respuesta anterior, ¿qué hizo usted como individuo y qué hizo su equipo como grupo para solucionar estos problemas o conflictos?

6. ¿Existían/existen miembros en $\mathrm{su} / \mathrm{s}$ equipo/s multicultural/es que hayan sido/sean más influyentes que otros? En caso afirmativo, ¿a qué causas atribuye usted esta situación?

7. ¿Cómo pueden los miembros de un equipo ser preparados para mejorar el trabajo en grupos multiculturales?

\footnotetext{
5 The guiding questions are reproduced in the Spanish version since all the interviews, with the exception of one in both rounds, were conducted in Spanish.
} 
ICOPROMO: Intercultural Competence for Professional Mobility

Second Round of Interviews

Guiding questions

1. Pregunta personalizada para cada entrevistado, basada en la conversación mantenida en la primera entrevista.

2. Algunos entrevistados comentan que las diferencias nacionales en un equipo multicultural son inexistentes. Otros estiman que tales diferencias existen y que son perceptibles (la gente parece saber, generalizando, cómo son los españoles, franceses, marroquíes, etc.) ¿Cuál es tu opinión?

3. Una gran parte de los entrevistados — si no todos - apuntan que la experiencia en un equipo multicultural ha sido enriquecedora. ¿Qué opinas al respecto? ¿Qué conocimientos has adquirido? ¿Han cambiado tus actitudes? ¿Qué habilidades o destrezas has desarrollado?

4. Si tuvieras la posibilidad de seleccionar a los integrantes de tu equipo multicultural, ¿qué cualidades tendrías en cuenta?

5. ¿Estás de acuerdo con que una participación efectiva en un grupo multicultural requiere una actitud / actuación democrática? De ser así, ¿se pueden suscitar temas como los derechos humanos, los derechos de las mujeres, etc.? ¿Podrías especificar cómo crees que se pueden abordar esos temas en un contexto laboral? ¿Cómo los has tratado tú según tu propia experiencia?

6. A menudo, tomando como referencia la 'teoría' y la 'práctica', escuchamos que en un equipo multicultural o multilingüe los hablantes nativos de la lengua de comunicación empleada probablemente tendrán una posición privilegiada en debates y discusiones y tendrán cierta ventaja con respecto a los demás. ¿Has experimentado este hecho? ¿Cómo crees que los hablantes nativos y no nativos de la lengua vehicular del equipo pueden solucionar este problema? 